\title{
IAMJ
}

INTERNATIONAL

AYURVEDIC

MEDICAL JOURNAL

\section{INTERRELATIONSHIP BETWEEN SATTVA SARATA AND EMOTIONAL INTELLIGENCE - AN OBSERVATIONAL STUDY}

\author{
Manisha Yadav', Srikanta Kumar Panda ${ }^{2}$, Nishi Arora ${ }^{3}$ \\ ${ }^{1}$ P.G. Scholar, PG Department of Kriya Sharir, Ayurveda and Unani Tibbia College New Delhi, India \\ ${ }^{2}$ Associate Professor, PG Department of Kriya Sharir, Ayurveda and Unani Tibbia College New Delhi, India \\ ${ }^{3}$ Associate Professor \& HOD, Department of Maulik Siddhanta \& Samhita, Ayurveda and Unani Tibbia College \\ New Delhi, India
}

Email: manishayadav9116@gmail.com

\section{https://doi.org/10.46607/iamjp04042020}

(Published online: May 2020)

Open Access

(C) International Ayurvedic Medical Journal, India 2020

Article Received: 07/04/2020 - Peer Reviewed: 18/04/2020 - Accepted for Publication: 07/05/2020

\section{Check for updates}

\begin{abstract}
In Ayurveda, the "Sara" word is used for the Vishuddhatara Dhatu (Tissue excellence). Sara is essence of Dhatu which provides strength and stability to the body. Determination of Sara of a person gives a clue of one's structural and metabolic characteristic as well as physical and mental disposition, which help to check out the line of treatment of a person and prescribing a favorable regimen and diet. Sattva Sara is the most purified form of Satt$v a$. The present study aims at assessing Sattva Sarata and Emotional Intelligence. The participants of the study were included 60 subjects between age group of 16 to 30 years. A proforma, specially designed on the basis of characteristics features describe in Brihattrayee for assess the Sattva Sarata. Emotional Intelligence was assessed by Mayer Salovey Caruso Emotional intelligence Test (MSCEIT). MSCEIT is based on a series of Emotion based problem solving items. Finding of the study revealed that the association in Sattva Sarata and Emotional Intelligence was statistically significant at $(\mathrm{P}$ value $<0.05)$.
\end{abstract}

Keywords: Sara, Sattva Sara, Emotional Intelligence 


\section{INTRODUCTION}

As per the core principles of Ayurveda the " $A y u$ " must be Sukhayu (best of individual health state) and Hitayu (Best of social harmony). In present fast paced life people are ignoring or unable to give proper attention towards their health. For maintaining a good health everybody should pay attention to maintain equilibrium in physical and mental status of the body. In Charaka Samhita ten assessment criteria are described to examine the strength and immunity of a person which are called as 'Dashavidha Parikshya Bhava'. Sarata Parikshan is explained by our Acharyas to determine the strength of Dhatu and strength of a person (Bala Pramana) ${ }^{1}$. Sara means an excellent genuine part of Dhatu that indicates the purity and efficiency of Dhatus ${ }^{2}$. In Ayurveda, the Sara word is used for the Vishuddhatara Dhatu ${ }^{3}$. The meaning of Sara as described by Sir Monier Williams is essence, excellent part of anything, the best part or quittances ${ }^{4}$. It is very important to examine Dhatu Sarata for determining the prognosis of the disease and for the determination of the dose of the drugs ${ }^{5}$.

The individuals have been classified into various categories on the rationale of Sara, depending upon the predominance of particular Dhatu in the body by virtue of its quantity, quality and functions. It is to be noted that individuals designated to particular Sara contain not only the essence of that particular Dhatu but may possess the essence of other Dhatu in some lesser proportion. On the basis of this inference Charaka and Vagbhata has categorized the individuals in following three groups ${ }^{6}$.

Pravara Sara: containing the essence of all the Dhatu and Sattva.

Madhyama Sara: contains the essence of all the Dhatu in moderate quantity.

Avara Sara: contains the essence of all the Dhatu at the minimal level.

Individuals having the excellence of mental faculties are characterized by excellence of Smriti (good memory), Bhakti (devotion), Kritagyata (gratefulness), Pragya (wisdom), Shuchi (purity of body, minds and ideas), Mahotsaha (enthusiasm), Daksha (skillful), Dhira (courageous), Samarvikranta Yodhi- nah (velour in fighting), Tyakta Vishada (absence of sorrow), Suvyavasthitagati (decision making), Gambhira Buddhi (depth of wisdom) and Kalyana Abhinivesha (sincerity in actions and virtuous acts) ${ }^{7}$.

People's appearance influences both their self-concept and their relationships with others. Intelligence is considered as one of the most desirable personality qualities in today's society. Emotions are involved in everything people do: every action, decision and Judgment. The part of the intellect that regulates emotion is known as Emotional intelligence. Emotional Intelligence in the simplest words refers to the ability to recognize and regulate emotions in us and others ${ }^{8}$, to make effective decisions. Emotions keep us making good decisions, and they keep us focusing 9 . "The ability to monitor one's own and others' feelings, to discriminate among them, and to use this information to guide one's thinking and action." (Mayer \& Salovey, 1997) ${ }^{10}$. The MSCEIT ${ }^{\mathrm{TM}}$ measures four related abilities:

Perceiving Emotions - the ability to correctly identify how people are feeling.

Using Emotions to Facilitate Thought - the ability to create emotions and to integrate your feelings into the way you think.

Understanding Emotions - the ability to understand the causes of emotions.

Managing Emotions - the ability to create effective strategies that use your emotions to help you achieve a goal, rather than being influenced by your emotions in unpredictable ways.

Human beings are a complex species of emotion and reason ${ }^{11}$. A person's Emotional Intelligence is very much influenced by his/her relationship history. Emotional Intelligence makes an important part of life, together with intellectual and relationship intelligence. The hustles and bustles of the urbanized era have compelled the humans into undefined and futile exercises which lead them towards disturbed mental state and emotional instability. Hence the Researcher felt the need to work upon it. The researcher could not find any satisfactory answer on the relationship between Sattva Sarata and Emotional Intelligence. 
So, the Researcher chose this topic to find some kind of clue for further studies in this regard and to contribute something positive for the society and country as a whole along with focus on individual's health and happiness.

\section{Objectives}

To establish Standard parameters to assess Sattva Sara and find out correlation between Sattva Sarata and Emotional Intelligence.

\section{Materials and Methods}

Study type - Observational.

Place of Study - Ayurvedic and Unani Tibia College,

Karol Bagh.

Sample Selection - Random sampling method.

Study Area - Karol Bagh

Inclusion Criteria - Healthy persons who are doing their daily activities easily and not suffering from any disease between the age group of 16years to 30years were included in the study.

Exclusion Criteria - Persons suffering from systemic diseases and age group below 16years and 30years were excluded from the study.

\section{Plan of study}

1. As per inclusion criteria, study was done in 60 subjects.

2. Sattva Sarata was examined by Ayurvedic questionnaire.

3. Emotional Intelligence of each subject was examined by MSCEIT.

4. Correlation of Sattva Sarata and Emotion Intelligence was calculated.

Criteria of Assessment

Assessment will be done on the basis of following gradations and scoring.

\section{OBSERVATION}

Table 1: Sattva Sarata

\begin{tabular}{|l|l|l|}
\hline Sattvasarata & Frequency & Percent \\
\hline Pravar & 35 & 58.33 \\
\hline Madhyam & 25 & 41.67 \\
\hline Avar & 0 & 0 \\
\hline
\end{tabular}

Table 2: Msceit Ability Emotional Intelligence

\begin{tabular}{|l|l|l|l|l|}
\hline \multirow{2}{*}{ Criteria } & Emotional intelligence & & \\
& Perceiving emotions & Using emotions & Understanding emotions & Managing emotions \\
\hline Expert & 16 & 11 & 12 & 13 \\
\hline Skilled & 30 & 28 & 19 & 30 \\
\hline Competence & 14 & 19 & 27 & 16 \\
\hline Developing & 0 & 2 & 2 & 1 \\
\hline Improve & 0 & 0 & 0 & 0 \\
\hline Total & 60 & 60 & 60 & 60 \\
\hline
\end{tabular}

Table 3: Emotional Intelligence In Percentage

\begin{tabular}{|l|l|l|l|l|}
\hline \multirow{2}{*}{ Criteria } & Emotional intelligence & \multicolumn{3}{l|}{} \\
\cline { 2 - 5 } & Perceiving emotions & Using emotions & Understanding emotions & Managing emotions \\
\hline Expert & $26.67 \%$ & $18.33 \%$ & $20.00 \%$ & $21.67 \%$ \\
\hline Skilled & $50.00 \%$ & $46.67 \%$ & $31.67 \%$ & $50.00 \%$ \\
\hline Competence & $23.33 \%$ & $31.67 \%$ & $45.00 \%$ & $26.67 \%$ \\
\hline Developing & $0.00 \%$ & $3.33 \%$ & $3.33 \%$ & $1.67 \%$ \\
\hline Improve & $0.00 \%$ & $0.00 \%$ & $0.00 \%$ & $0.00 \%$ \\
\hline
\end{tabular}




\section{Hypothesis}

H0 - Sattva Sarata and Emotional Intelligence are independent.

H1 - Sattva Sarata and Emotional Intelligence are not independent.

Table 4: Sattva Sarata And Perceiving Emotions

\begin{tabular}{|l|l|l|l|l|}
\hline \multirow{2}{*}{ SattvaSarata } & Perceiving emotions & \multicolumn{2}{l}{ Total } \\
\hline \multirow{2}{*}{ Pravar } & Expert & Skilled & Competence & \\
\hline \multirow{2}{*}{ Madhyam } & 11 & 20 & 4 & 35 \\
\hline \multirow{2}{*}{ Total } & $18.33 \%$ & $33.33 \%$ & $6.67 \%$ & $58.33 \%$ \\
\hline & 5 & 10 & 10 & 25 \\
\hline & $8.33 \%$ & $16.67 \%$ & $16.67 \%$ & $41.67 \%$ \\
\hline & 16 & 30 & 14 & 60 \\
\hline & $26.67 \%$ & $50.00 \%$ & $23.33 \%$ & $100.00 \%$ \\
\hline
\end{tabular}

Table 5: Sattva Sarata And Using Emotions

\begin{tabular}{|l|l|l|l|l|l|}
\hline \multirow{2}{*}{ Sattva Sarata } & Using emotions & \multicolumn{3}{l|}{ Total } \\
\cline { 2 - 5 } & Expert & Skilled & Competence & Developing & \\
\hline Pravar & 11 & 17 & 6 & 1 & 35 \\
\cline { 2 - 5 } & $18.33 \%$ & $28.33 \%$ & $10.00 \%$ & $1.67 \%$ & $58.33 \%$ \\
\hline Madhyam & 0 & 11 & 13 & 1 & 25 \\
\cline { 2 - 5 } & $0.00 \%$ & $18.33 \%$ & $21.67 \%$ & $1.67 \%$ & $41.67 \%$ \\
\hline & 11 & 28 & 19 & 2 & 60 \\
\hline & $18.33 \%$ & $46.67 \%$ & $31.67 \%$ & $3.33 \%$ & $100.00 \%$ \\
\hline
\end{tabular}

Table 6: Sattva Sarata And Understanding Emotions

\begin{tabular}{|l|l|l|l|l|l|}
\hline \multirow{2}{*}{ Sattva Sarata } & \multicolumn{4}{l|}{ Understanding emotions } & Total \\
\cline { 2 - 5 } & Expert & Skilled & Competence & Developing & \\
\hline \multirow{2}{*}{ Pravar } & 11 & 11 & 12 & 1 & 35 \\
\cline { 2 - 5 } & $18.33 \%$ & $18.33 \%$ & $20.00 \%$ & $1.67 \%$ & $58.33 \%$ \\
\hline \multirow{2}{*}{ Total } & 1 & 8 & 15 & 1 & 25 \\
& $1.67 \%$ & $13.33 \%$ & $25.00 \%$ & $1.67 \%$ & $41.67 \%$ \\
\hline & 12 & 19 & 27 & 2 & 60 \\
\cline { 2 - 5 } & $20.00 \%$ & $31.67 \%$ & $45.00 \%$ & $3.33 \%$ & $100.00 \%$ \\
\hline
\end{tabular}

Table 7: Sattva Sarata And Managing Emotions

\begin{tabular}{|l|l|l|l|l|l|}
\hline \multirow{2}{*}{ SattvaSarata } & \multicolumn{4}{l|}{ Managing emotions } & \multicolumn{2}{l}{ Total } \\
\cline { 2 - 5 } & Expert & Skilled & Competence & Developing & \\
\hline \multirow{2}{*}{ Pravar } & 12 & 16 & 7 & 0 & 35 \\
\cline { 2 - 5 } & $20.00 \%$ & $26.67 \%$ & $11.67 \%$ & $0.00 \%$ & $58.33 \%$ \\
\hline Madhyam & 1 & 14 & 9 & 1 & 25 \\
\hline Total & $1.67 \%$ & $23.33 \%$ & $15.00 \%$ & $1.67 \%$ & $41.67 \%$ \\
\hline & 13 & 30 & 16 & 1 & 60 \\
\hline & $21.67 \%$ & $50.00 \%$ & $26.67 \%$ & $1.67 \%$ & $100.00 \%$ \\
\hline
\end{tabular}




\section{DISCUSSION}

\section{Sattva Sara Distribution}

Assessment of Sattva Sarata was done by Prashna Pariksha. As per inclusion criteria 60 subjects were included in this study. There were total 13 Lakshnas in Sattva Sarata by Carak Acharya, each Lakshanas has one leading questions, so there were 13 questions in the questionnaire of Sattva Sarata. The score less than or equal to $33.33 \%$ was graded as Avara Sattva Sarata. In between $33.33 \%$ - $66.66 \%$ was graded as Madhyama Sattva Sarata and score greater than 66.66\% was graded as Pravara Sattva Sarata.

The present study demonstrated that 35 i.e. 58.33\% exhibited predominantly Pravara Sattva Sarata while 25 i.e. $41.67 \%$ exhibited Madhyama and 0 i.e. $0 \%$ exhibited Avara Sattva Sarata.

The Pravara Sattva Sara group people are described to have authoritative speech, have better power of understanding and retention, show purity, have high intellect, are eloquent, are away from pride, ego, greed, jealousy. They are far sighted, like virtuous acts and like poetry, stories and epics.

\section{Emotional Intelligence Distribution}

Emotional Intelligence was assessed by Mayer Salovey Caruso Emotional intelligence Test (MSCEIT). MSCEIT is based on a series of Emotion based problem solving items.

A score range is provided in order to help you interpret your results. This score range is an estimate of your actual ability. The ranges are defined as follows:

Improve: You may have some difficulty in this area. It would be helpful to enhance your skills and knowledge.

Consider Developing: While this is not strength, you can consider enhancing this skill area if it is an important part of your daily life.

Competent: You have sufficient skill to perform in this area with some degree of success. Skilled: This is an area of strength for you.

Expert: This may be a highly developed area of expertise; your score suggests that you have great potential in this area.

Emotional intelligence subdivision perceiving emotions had 16 (26.67\%) Expert, 30 (50\%) Skilled and
$14(23.33 \%)$ Competence respectively. Emotional intelligence subdivision Using emotions had 11 (18.33\%) Expert, 28 (46.67\%) Skilled, 19 (31.67\%) Competence and 2 (3.33\%) Developing respectively. Emotional intelligence subdivision Understanding emotions had 12 (20\%) Expert, 19 (31.67\%) Skilled, 27 (45\%) Competence and 2 (3.33\%) Developing respectively. Emotional intelligence subdivision Managing emotions had 13 (21.67\%) Expert, 30 (50\%) Skilled, 16 (26.67\%) Competence and 1 (1.67\%) Developing respectively.

\section{Sattva Sarata And Emotional Intelligence}

This study is primarily aimed at to study relation between Sattva Sarata and Emotional Intelligence. It is observed that Emotional Intelligence subdivision Perceiving emotions had 35 (58.33\%) Pravar Sattva participants out of which $11(18.33 \%)$ expert, 20 $(33.33 \%)$ skilled and $4(6.67 \%)$ are competence. 25 (41.67\%) participants belongs to Madhyam Sattva out of which 5 (8.33\%) expert, 10 (16.67\%) skilled and 10 $(16.67 \%)$ are competence.

Emotional Intelligence subdivision Using emotions had 35 (58.33\%) Pravar Sattva participants out of which $11(18.33 \%)$ expert, 17 (28.33\%) skilled, 6 (10\%) competence and $1(1.67 \%)$ are Consider Developing. 25 (41.67\%) participants belongs to Madhyam Sattva out of which $0(0 \%)$ expert, $11(18.33 \%)$ skilled, $13(21.67 \%)$ competence and $1(1.67 \%)$ are Consider Developing.

Emotional Intelligence subdivision Understanding emotions had 35 (58.33\%) Pravar Sattva participants out of which 11 (18.33\%) expert, 11 (18.33\%) skilled, $12(20 \%)$ competence and $1(1.67 \%)$ are Consider Developing. $25(41.67 \%)$ participants belongs to Madhyam Sattva out of which 12 (20\%) expert, 19 (31.67\%) skilled, 27 (45\%) competence and 2 (3.33\%) are Consider Developing.

Emotional Intelligence subdivision Managing emotions had 35 (58.33\%) Pravar Sattva participants out of which $12(20 \%)$ expert, 16 (26.67\%) skilled, 7 (11.67\%) are competence. $25(41.67 \%)$ participants belongs to Madhyam Sattva out of which 13 (21.67\%) expert, 30 (50\%) skilled, 16 (26.67\%) competence and $1(1.67 \%)$ are Consider Developing. 
To find out relation between Sattva Sarata and Emotional Intelligence, the Chi-square test of association was applied, it was significant at $\mathrm{p}<0.05$, there is a relation between Sattva Sarata and Emotional Intelligence.

\section{CONCLUSION}

On administration of the test to assess the grade of Sattva Sarata, 35 (58.33\%) show Pravara Sattva Sarata, 25 (41.67\%) exhibited predominantly Madhyama Sattva Sarata and in the study there were no subjects of Avar Sattva Sara. According to study it was concluded that in the perceiving emotion, 30 subjects were skilled out of 60 subjects. In the using emotion 28 subjects were skilled out of 60 subjects. In the understanding emotion 19 subjects were skilled and in the managing emotion 30 subjects were skilled. The overall result shows that total msceit score is in the skilled range. This score indicates that you are aware of emotions in yourself and in others, and that your perception and understanding of emotion is accurate. We can draw a conclusion at the end of study that there is a relation between Sattva Sarata and Emotional Intelligence.

\section{REFERENCES}

1. Acharya J T, Charaka samhita by Agnivesa with Ayurveda deepikateeka of Chakrapanidatta, Vimanasthana, Rogabhishagjitiyavimanaa adhyaye, Reprint ed, Varanasi: Chaukhambha Orientalia, 2011; 8:102, p. 278.

2. Apte V S Revised and enlarged edition, The practical Sanskrit-English dictionary. Poona: Prasad Prakashan, 1957-1959; 3v.1673.

3. Acharya J T, Charaka samhita by Agnivesa with Ayurveda deepikateeka of Chakrapanidatta, Vimanasthana, Rogabhishagjitiyavimanaa adhyaye, Reprint ed, Varanasi: Chaukhambha Orientalia, 2011; 8:102, p. 278.

4. Williams M, An English Sanskrit Dictionary, Reprint ed, New delhi: Bharatiya Granth Niketan, 2006; p. 549.

5. Acharya J T, Acharya N R, Sushruta samhita of Sushruta, Nibandha Sangraha vyakhya of Dalhana, Sutrasthana, Aturaupkramaniya adhyaye, $7^{\text {th }} \mathrm{ed}$. Varanasi: Chaukhamba Orientalia, 2002; 35:16, p.152.

6. Acharya J T, Charaka samhita by Agnivesa with Ayurveda deepikateeka of Chakrapanidatta, Vimanasthana,
Rogabhishagjitiyavimanaa adhyaye, Reprint ed. Varanasi: Chaukhambha Orientalia, 2011; 8:112,113, p. 278.

7. Acharya J T, Charaka samhita by Agnivesa with Ayurveda deepikateeka of Chakrapanidatta, Vimanasthana, Rogabhishagjitiyavimanaa adhyaye, Reprint ed. Varanasi: Chaukhambha Orientalia, 2011; 8:110, p. 278.

8. Goleman, D, The Emotionally Intelligent Workplace, Jossey-Bass, 2001

9. Warner, J, Emotional Intelligence Assessment. Ready To Manage, Inc, 2010

10. Peter Salovey and Daisy Grewal, The Science of Emotional Intelligence Source: Current Directions in Psychological Science, 2005; Vol. 14, No. 6. p. 281-285.

11. N. Gayathri, Dr. K. Meenakshi, "A Literature of Emotional Intelligence”, IJHSSI, 2013; 2(3), p.42-45.

\section{Source of Support: Nil Conflict of Interest: None Declared}

How to cite this URL: Manisha Yadav et al: Interrelationship Between Sattva Sarata And Emotional Intelligence - An Observational Study. International Ayurvedic Medical Journal \{online\} 2020 \{cited May, 2020\} Available from: http://www.iamj.in/posts/images/upload/2303 2308.pdf 